\title{
PHYSICAL ACTIVITY IN STUDENTS FROM THE VISEGRAD COUNTRIES BY BMI STATUS
}

\section{AKTYWNOŚĆ FIZYCZNA STUDENTÓW W KRAJACH GRUPY WYSZEHRADZKIEJ WEDŁUG WSKAŹNIKA BMI}

\author{
Ján Junger ${ }^{1(A, B, D, E, F)}$, Karel Frömel ${ }^{2(B, C, E)}$, Józef Bergier $^{3(A, B, D)}$, Pongrác Ács ${ }^{4(B, G)}$, \\ Barbara Bergier $^{3(B, F)}$, Ferdinand Salonna ${ }^{2(B, C)}$, Ewelina Niźnikowska ${ }^{3(B, F)}$
}

\author{
${ }^{1}$ Pavol Jozef Šafárik University in Košice, the Slovak Republic \\ ${ }^{2}$ Palacký University, the Czech Republic \\ ${ }^{3}$ Pope John Paul II State School of Higher Education in Biała Podlaska, Poland \\ ${ }^{4}$ University of Pécs, Hungary
}

Authors' contribution

Wkład autorów:

A. Study design/planning

zaplanowanie badań

B. Data collection/entry

zebranie danych

C. Data analysis/statistics

dane - analiza i statystyki

D. Data interpretation

interpretacja danych

E. Preparation of manuscript

przygotowanie artykułu

F. Literature analysis/search wyszukiwanie i analiza literatury

G. Funds collection

zebranie funduszy
Tables: 7

Figures: 0

References: 21

Submitted: 2017 Nov 30

Accepted: 2017 Apr 21

\section{Summary}

Background. This study aims to analyse the relationship between physical activity (PA) and body mass index (BMI) in undergraduate university students of three fields of study from the four Visegrad Group countries - Slovakia, the Czech Republic, Poland, and Hungary.

Material and methods. The research was conducted in 2015 on adolescent undergraduate university student populations in three fields of study - humanities, medical, and technical sciences. The sample included 2,484 students in total. The data was collected using the extended version of the standardised International Physical Activity Questionnaire (IPAQ). Students completed the questionnaire via the INDARES online system.

Results. The results confirmed significant differences in PA between sexes in favour of males both in its overall manifestation and in the individual levels of PA intensity $(p<0.05)$. The comparison of the four countries revealed significant differences in PA in males and females in all PA domains $(p<0.05)$. The evaluation of the total BMI, as well as the one measured in individual countries confirmed a significant difference between sexes in favour of males $(p<0.05)$. The study of the relationship between PA and BMI did not reveal a statistically significant dependence in any of the tested domains. This conclusion applies both to males and females.

Conclusions. Males are generally more physically active than females overall and in individual fields of study. Also, males exhibit higher BMI in all the studied categories. No significant relation between PA intensity and volume and BMI was found in either sex.

Keywords: student, field of study, IPAQ, BMI, V4

\section{Streszczenie}

Wprowadzenie. Celem badania jest analiza związku pomiędzy aktywnością fizyczną (PA) a wskaźnikiem masy ciała (BMI) u studentów studiów licencjackich z trzech kierunków z czterech krajów Grupy Wyszehradzkiej - Słowacji, Czech, Polski i Wegier.

Materiał i metody. Badania przeprowadzono w $2015 \mathrm{r}$. Na studiach dla młodzieży z trzech kierunków: humanistycznym, medycznym i technicznym. Próba obejmowała ogółem 2484 studentów. Dane zebrano za pomocą długiej wersji standardowego Międzynarodowego Kwestionariusza Aktywności Fizycznej (IPAQ). Studenci wypełniali ankietę za pośrednictwem systemu internetowego INDARES.

Wyniki. Wyniki potwierdziły istotne różnice w PA między płciami na korzyść mężczyzn zarówno w ich ogólnej aktywności, jak i w poszczególnych poziomach intensywności PA $(\mathrm{p}<0,05)$. Porównanie czterech krajów wykazało istotne różnice w PA u mężczyzn (z wyjątkiem PA w czasie wolnym), a także u kobiet we wszystkich obszarach PA $(\mathrm{p}<0,05)$. Najbardziej aktywni fizycznie spośród badanych grup byli polscy mężczyźni i słowackie kobiety. Ocena BMI ogółem oraz w poszczególnych krajach potwierdziła istotna różnice między płciami na korzyść mężczyzn $(\mathrm{p}<0,05)$. Badanie zależności między PA i BMI nie wykazało statystycznie istotnej zależności w żadnej z kategorii. Wniosek ten dotyczy zarówno mężczyzn, jak i kobiet.

Wnioski. Mężczyźni są fizycznie bardziej aktywni niż kobiety ogólnie i na poszczególnych kierunkach. Mężczyźni mają również wyższy BMI we wszystkich badanych kategoriach. Nie stwierdzono istotnej zależności między intensywnością i objętością PA a BMI u obu płci.

Słowa kluczowe: student, kierunek studiów, IPAQ, BMI, V4

Junger J, Frömel K, Bergier J, Ács P, Bergier B, Salonna F, et al. Physical activity in students from the Visegrad countries by BMI status. Health Prob Civil. 2018; 12(1): 41-48. https://doi.org/10.5114/hpc.2018.74191

Address for correspondence / Adres korespondencyjny: Ján Junger, Pavol Jozef Šafárik University in Košice, Slovak Republic, Ondavská 21, 040 01 Košice, the Slovak Republi, e-mail: jan.junger@upjs.sk

Copyright: (C) Pope John Paul II State School of Higher Education in Biała Podlaska, Ján Junger, Karel Frömel, Józef Bergier, Pongrác Ács, Barbara Bergier, Ferdinand Salonna, Ewelina Niźnikowska. This is an Open Access journal, all articles are distributed under the terms of the Creative Commons Attribution-NonCommercialShareAlike 4.0 International (CC BY-NC-SA 4.0) License (http://creativecommons.org/licenses/by-nc-sa/4.0/), allowing third parties to copy and redistribute the material in any medium or format and to remix, transform, and build upon the material, provided the original work is properly cited and states its license. 


\section{Introduction}

Despite the numerous and scientifically proven facts about the need and significance of regular physical activity (PA) in people's lives, there is no positive response in today's people's lifestyles. As a result, this is the first time in human history that people are not prepared to do something about the absence of PA caused by changes in lifestyle or do not think about it as they do not fully feel the consequence of such an attitude during ontogenesis [1]. What is worse, people tend to pass on bad habits formed during childhood and adolescence to adulthood. A young person's transfer from high school to university could serve as an example. On the one hand, the number of hours spent sitting at a school desk decreases due to a different organisation of classes at the two institutions [2]; on the other hand, the fact that universities vary their study plans forces students to limit their leisure time and become more responsible for their course programme [3,4]. Also, to a large extent, young people's relationship with PA is limited by the contemporary lifestyle [5]. In our perspective, there is a constant clash in attitudes towards active and inactive pastimes, resulting in a decrease in PA and an increase in inactive lifestyles [6]. Yet physical activity is of irreplaceable importance not only in health promotion and disease prevention but also in the process of socialisation and formation of proper habits in children and youth. From this and other points of view, it seems vital to know that today's population of children and adolescents demonstrate a lower PA level than the biological need. The minimum demand for PA is delimited by the so-called threshold level; an amount of PA necessary for healthy development of an organism. The threshold level changes over time with an individual's age [7]. According to Sallis and Patrick (1994), adolescents should be physically active daily or almost every day. They should engage in at least 30 minutes of low-intensity PA every day and at least 20 minutes of vigorous PA at least three times a week [8]. LeMasurier et al. (2003) consider this threshold to be ten thousand steps per day [9], which, in principle, corresponds to the Healthy People 2010 recommendations on promotion of health in adult populations [10].

Among the consequences of an unhealthy lifestyle with limited PA, one should mention an increased prevalence of obesity [11]. An adequate weight in an individual is ensured by a proper balance between energy intake and expenditure. However, the contemporary lifestyle has disturbed this balance, which is mostly due to physical inactivity [12] and low-quality food, offered by an ever-increasing number of fast-food establishments, which are consumed with highly sweetened beverages [13]. The quality of contemporary diet and nutrition is significantly influenced by changes in the eating habits of whole families, the prevalence of a sedentary lifestyle, and the media [14].

This is one of the reasons why the abovementioned problem of defining the threshold PA levels is not the only that is being discussed nowadays. Also, the question of PA's influence on human body composition is raised. Monitoring children and adolescents' basic physical characteristics does not serve to assess their appearance, but is also a crucial means of assessing their current health. To determine the presence or absence of obesity or measure whether a person's body weight is adequate for their height, the body mass index (BMI) is currently used. This index is widely applied and easily calculable, but because it does not take into account the muscle to fat ratio its use is only appropriate for non-athletes [15]. The research focused on monitoring the body composition of physically active and inactive people shows that PA positively impacts the percentage of non-fat tissue by increasing its volume and decreasing the amount of body fat [16]. Furthermore, as Hendl, Dobrý et al. (2011) point out, active engagement of youth in sports has a proven effect on lower BMI in adulthood [17].

This study's objective was to analyse the relationship between PA and the body mass index (BMI) in undergraduate university students in three fields of study. The students came from the four countries of the Visegrad Group - Slovakia, the Czech Republic, Poland, and Hungary.

\section{Material and methods}

The project was designed so that the data would be collected in cities with 50-200 thousand inhabitants. Basing on the requirements, four universities partook in this research: Faculty of Sports, the University of Prešov in Prešov, Slovak Republic; Palacký University, Czech Republic; Pope John Paul II State School of Higher Education, Biała Podlaska, Poland; and University of Pécs, Hungary.

The study was conducted in 2015 on adolescent undergraduate university students of three fields of study - humanities, as well as medical and technical courses. In total, the sample included 2,484 persons. Due to incomplete data or mistakes and errors in the answer sheets, the statistical analysis was performed on the sample of 2,176 students - 1,033 males (47.5\%) and 1,143 females (52.5\%). The data was collected using the extended self-administered version of the standardised International Physical Activity Questionnaire [18]. The IPAQ defines physical activity levels as follows: a low activity level of 600 MET-min/week, a medium activity level of 600-1,500 MET-min/week, and a high activity level of more than 1,500 MET-min/week. The IPAQ 
distinguishes between sedentary, moderate, and vigorous activities, such as sports or household chores, to which different MET values are assigned. Students completed the questionnaire in class via the INDARES online system. The surveys gave us information about the individuals' height, body weight, and amount of weekly PA in these categories: vigorous and moderate PA, walking, school-related PA, transportation PA, housework PA, and recreation, sport, and leisure-time PA.

The ANOVA method, the Pearson correlation coefficient, the Kruskal-Wallis test, and the Mann-Whitney $\mathrm{U}$ test were used for statistical analysis. The level of statistical significance was set at $\mathrm{p}<0.05$.

\section{Results}

Our first goal was to compare university students' PA by sex. Basing on the collected data, we could reject our hypothesis that sex plays no significant role in university students' partaking in PA. It turned out that physical activity expressed in MET-min/week is higher among males than females $(\mathrm{p}<0.05)$ not only in the overall amount of PA (M = 5,971.77 MET-min/week, F = 5,177.96 MET-min/week) and in its individual categories but also in special recreational and sport activities carried out in leisure time (Table 1).

Table 1. Mean physical activity MET/week/sex

\begin{tabular}{|c|c|c|c|}
\hline & male & female & sig \\
\hline MET total & $5971.77^{*}$ & 5177.96* & .013 \\
\hline Vigorous MET total & 1932.56* & 1239.83* & .000 \\
\hline Moderate MET total & 2416.69 & 2154.45 & .136 \\
\hline Walking MET total & $1622.52 *$ & 1783.68* & .006 \\
\hline Job-related physical activity total MET & 1875.76* & 1498.06* & .001 \\
\hline Transportation physical activity total MET & 1145.22 & 1088.72 & .808 \\
\hline Housework, house maintenance, and caring for family total MET & 1131.19* & 1124.08* & .007 \\
\hline Recreation, sport, and leisure-time physical activity total MET & 1819.59* & 1467.09* & .000 \\
\hline
\end{tabular}

MET = metabolic equivalent, statistics = Mann-Whitney U test,

* the significance level is 0.05

In addition to the information about the students' overall PA, we were also interested in PA intensity. The Kruskal-Wallis test revealed differences $(\mathrm{p}<0.05)$ in PA intensity between sexes as well. We found that male students prefer vigorous PA to moderate PA, whereas the opposite is true of female students.

We were, therefore, interested in discovering how the students' attitude towards PA is manifested in the individual fields of study (Table 2).

Table 2. Mean physical activity MET/week/grade/sex

\begin{tabular}{|c|c|c|c|c|c|c|}
\hline & \multicolumn{3}{|c|}{ male } & \multicolumn{2}{c|}{ female } \\
\cline { 2 - 7 } & $\begin{array}{c}\text { university } \\
\text { humanities } \\
\text { field }\end{array}$ & $\begin{array}{c}\text { university } \\
\text { medical } \\
\text { field }\end{array}$ & $\begin{array}{c}\text { university } \\
\text { technical } \\
\text { field }\end{array}$ & $\begin{array}{c}\text { university } \\
\text { humanities } \\
\text { field }\end{array}$ & $\begin{array}{c}\text { university } \\
\text { medical } \\
\text { field }\end{array}$ & $\begin{array}{c}\text { university } \\
\text { technical } \\
\text { field }\end{array}$ \\
\hline MET total & $\mathbf{6 4 9 5 . 2 0 *}$ & $\mathbf{7 1 1 1 . 6 4 *}$ & $\mathbf{5 0 8 5 . 4 6 *}$ & 5269.91 & 5246.68 & 4969.04 \\
\hline Vigorous MET total & $\mathbf{2 2 7 3 . 0 9 *}$ & $\mathbf{2 3 8 5 . 8 1 *}$ & $\mathbf{1 5 0 9 . 7 5 *}$ & 1234.01 & 1316.64 & 1136.47 \\
\hline Moderate MET total & 2597.09 & 2587.63 & 2229.62 & 2179.72 & 1967.32 & 2392.99 \\
\hline Walking MET total & $\mathbf{1 6 2 5 . 0 2 *}$ & $\mathbf{2 1 3 8 . 2 0 *}$ & $\mathbf{1 3 4 6 . 0 9 *}$ & 1856.19 & 1962.72 & 1439.59 \\
\hline $\begin{array}{c}\text { Job-related physical activity total } \\
\text { MET }\end{array}$ & 2044.50 & 2363.20 & 1526.04 & 1442.16 & 1717.37 & 1250.00 \\
\hline $\begin{array}{c}\text { Transportation physical activity } \\
\text { total MET }\end{array}$ & 1136.48 & 1334.98 & 1048.64 & 1093.06 & 1101.66 & 1064.93 \\
\hline $\begin{array}{c}\text { Housework, house maintenance, } \\
\text { and caring for family total MET }\end{array}$ & 1275.61 & 1193.30 & 1021.30 & 1175.23 & 1041.09 & 1182.03 \\
\hline $\begin{array}{c}\text { Recreation, sport, and leisure-ti- } \\
\text { me physical activity total MET }\end{array}$ & $\mathbf{2 0 3 8 . 6 1 *}$ & $\mathbf{2 2 2 0 . 1 6 *}$ & $\mathbf{1 4 8 9 . 4 8 *}$ & 1559.47 & 1386.56 & 1472.08 \\
\hline
\end{tabular}

MET = metabolic equivalent, statistics = Kruskal-Wallis test,

*the significance level is 0.05 
Significant differences $(\mathrm{p}<0.05)$ between fields of study were only found in males - the most active are those in the medical field of study when it comes to recreation and sports PA (2,220.16 NET-min/week), vigorous PA (2,385.81 MET-min/week), and overall PA (7,111.64 MET-min/week).

As for the students' PA by country (Table 3), we found no significant differences $(\mathrm{p}<0.05)$ in males in any of the individual PA categories, except for recreation and sports PA as well as transportation PA.

Table 3. Mean physical activity MET/week/country of study/male

\begin{tabular}{|c|c|c|c|c|c|}
\hline & Slovakia & Poland & $\begin{array}{c}\text { Czech } \\
\text { Republic }\end{array}$ & Hungary & sig. \\
\hline MET total & 5382.11* & 7477.54* & 7165.74* & 3325.50* & .00 \\
\hline Vigorous MET total & 1694.50* & $2390.45^{*}$ & 2327.85* & 1162.14* & .00 \\
\hline Moderate MET total & $2327.11^{*}$ & 2938.43* & $2806.43^{*}$ & $1397.69 *$ & .00 \\
\hline Walking MET total & 1360.49* & 2148.66* & 2031.46* & 765.67* & .00 \\
\hline $\begin{array}{c}\text { Job-related physical activity total } \\
\text { MET }\end{array}$ & 1854.68* & 2599.21* & $2428.76^{*}$ & $340.24^{*}$ & .00 \\
\hline $\begin{array}{c}\text { Transportation physical activity total } \\
\text { MET }\end{array}$ & 1095.68* & 1529.58* & $1520.18 *$ & $297.62^{*}$ & .00 \\
\hline $\begin{array}{l}\text { Housework, house maintenance, and } \\
\text { caring for family total MET }\end{array}$ & 975.47* & 1364.89* & $1322.27 *$ & $784.52 *$ & .00 \\
\hline $\begin{array}{l}\text { Recreation, sport, and leisure-time } \\
\text { physical activity total MET }\end{array}$ & 1456.28 & 1983.86 & 1894.53 & 1903.12 & .258 \\
\hline
\end{tabular}

MET - metabolic equivalent, statistics: Kruskal-Wallis Test,

*the significance level is 0.05

On the other hand, there were significant differences $(\mathrm{p}<0.05)$ in females (Table 4) in all PA forms. Overall, the most physically active are Slovak female university students (7,075.89 MET-min/week), while the least physically active are Hungarian female students (3,626.90 MET-min/week).

Table 4. Mean physical activity MET/week/country of study/female

\begin{tabular}{|c|c|c|c|c|c|}
\hline & Slovakia & Poland & $\begin{array}{c}\text { Czech } \\
\text { Republic }\end{array}$ & Hungary & sig. \\
\hline MET total & $7075.89^{*}$ & $5049.28^{*}$ & $5144.46^{*}$ & $3626.90^{*}$ & .00 \\
\hline Vigorous MET total & $1914.40^{*}$ & $1024.04^{*}$ & $1139.30^{*}$ & $1016.65^{*}$ & .00 \\
\hline Moderate MET total & $2393.85^{*}$ & $2273.17^{*}$ & $2208.47^{*}$ & $1711.20^{*}$ & .00 \\
\hline Walking MET total & $2767.64^{*}$ & $1752.07^{*}$ & $1796.70^{*}$ & $899.05^{*}$ & .00 \\
\hline $\begin{array}{c}\text { Job-related physical activity total } \\
\text { MET }\end{array}$ & $2600.95^{*}$ & $1500.78^{*}$ & $1551.24^{*}$ & $413.19^{*}$ & .00 \\
\hline $\begin{array}{c}\text { Transportation physical activity total } \\
\text { MET }\end{array}$ & $1497.31^{*}$ & $1209.66^{*}$ & $1246.66^{*}$ & $375.45^{*}$ & .00 \\
\hline $\begin{array}{c}\text { Housework, house maintenance, and } \\
\text { caring for family total MET }\end{array}$ & $1286.41^{*}$ & $1158.88^{*}$ & $1106.85^{*}$ & $943.43^{*}$ & .015 \\
\hline $\begin{array}{c}\text { Recreation, sport, and leisure-time } \\
\text { physical activity total MET }\end{array}$ & $1691.23^{*}$ & $1179.96^{*}$ & $1239.72^{*}$ & $1894.83^{*}$ & .00 \\
\hline
\end{tabular}

MET - metabolic equivalent, statistics: Kruskal-Wallis Test,

*the significance level is 0.05

The other studied variable was the BMI height-weight index. Similarly to overall PA, there were significant differences $(\mathrm{p}<0.05)$ between sexes in BMI as well (Table 5).

Table 5. BMI - description by sex

\begin{tabular}{|c|c|c|c|c|}
\hline Sex & Mean & Std. deviation & F & Sig. \\
\hline male & 24.13 & 3.403 & \multirow{2}{*}{ 341.054* } & .000 \\
\hline female & 21.54 & 3.142 & & \\
\hline total & 22.77 & 3.515 & & \\
\hline
\end{tabular}

BMI - Body mass index, statistics: Anova, F - test criterion* 
After comparing the individual categories of BMI, we can confirm that a few more than three quarters of the observed students have a healthy BMI, more than $20 \%$ are overweight, and almost $10 \%$ are underweight (Table 6).

Table 6. BMI category - description by sex

\begin{tabular}{|c|c|c|c|c|c|c|}
\hline & \multicolumn{2}{|c|}{ underweight } & \multicolumn{2}{|c|}{ healthy weight } & \multicolumn{2}{|c|}{ overweight } \\
\hline & count & row n \% & count & row n \% & count & row n \% \\
\hline male & 30 & 2.9 & 649 & 62.8 & 354 & 34.3 \\
\hline female & 151 & 13.2 & 848 & 74.2 & 144 & 12.6 \\
\hline total & 181 & 8.3 & 1497 & 68.8 & 498 & 22.9 \\
\hline
\end{tabular}

BMI - Body mass index

Our main research objective was to analyse whether there is a relation between BMI and PA in university students. Using the Pearson correlation coefficient (and, where appropriate, the Spearman correlation coefficient as a verification means), we discovered that neither overall BMI nor individual BMI categories have any significant relation to the particular forms of PA performed by the students (Table 7).

Table 7. Correlation between BMI/BMI category and individual components of physical activity

\begin{tabular}{|c|c|c|c|c|}
\hline & \multicolumn{2}{|c|}{ male } & \multicolumn{2}{c|}{ female } \\
\hline & BMI & BMI category & BMI & BMI category \\
\hline BMI & 1 & .811 & 1 & .798 \\
\hline BMI category & .811 & 1 & .798 & -.036 \\
\hline Walking MET total & -.056 & -.085 & -.033 & .003 \\
\hline Moderate MET total & .004 & -.010 & .044 & -.018 \\
\hline Vigorous MET total & -.023 & -.038 & -.013 & -.021 \\
\hline MET total & -.028 & -.050 & .003 & -.041 \\
\hline Job-related physical activity total MET & -.042 & -.072 & -.031 & -.022 \\
\hline $\begin{array}{c}\text { Houseworkportation physical activity total MET } \\
\text { fause maintenance, and caring for }\end{array}$ & -.013 & -.020 & -.006 & .013 \\
\hline $\begin{array}{c}\text { Recreation, sport, and leisure-time physical } \\
\text { activity total MET }\end{array}$ & .026 & .000 & .044 & .004 \\
\hline Physical activity level & .002 & -.008 & .027 & .048 \\
\hline
\end{tabular}

BMI - Body mass index

\section{Discussion}

The PA results obtained through this international Visegrad Fund research show differences in PA realisation between sexes in the surveyed university students (Table 1). Males are significantly more physically active overall and in most of the studied categories $(\mathrm{p}<0.05)$, except transportation PA and moderate PA, which did not show statistical significance in the Mann-Whitney U test. Paradoxically, these two PA components come first and second, volume-wise, in males' overall PA structure. In females, PA structure is comprised mostly of moderate intensity PA, job-related PA, and recreation, sport, and leisure-time PA. Comparing our results with the results of the studies conducted in comparable surrounding countries, we can conclude that our sample was more physically active in all categories. In the newest research, Czech students reported PA levels of 5,758 (males) and 4,502 (females) MET-min/week [2]. Much lower levels were found in a sample of Ukrainian university students who reported on average 3,560.5 MET-min/week [19]. In a similar study conducted on Ukrainian youth aged 17 to 22, males reported PA levels of 3,863 and females of 3,365 MET-min/week [21]. Polish youth aged 16 to 18 , which is partially comparable to the age of university freshmen, reported even lower levels of PA - 2,640 (males) and 2,219 (females) MET-min/week [22]. According to sex, both in our study and in other similar research, males are physically more active than females.

As already indicated in the results section, the difference in interest in PA between sexes is complemented by the results of PA intensity analysis. As many as $60 \%$ of male students prefer vigorous PA to moderate PA (35 
\%). In female students, the situation is entirely opposite - vigorous PA is followed by approx. $45 \%$, but moderate PA by as much as half of the sample. What is positive about this comparison is that both groups prefer moderate and vigorous PA to low-intensity PA.

When analysing PA volume in individual fields of study (Table 2), we discovered that significant differences $(p<0.05)$ were present only in males in overall PA and three of its components - moderate PA, walking, and recreation, sport, and leisure-time PA. In all of these cases, the most physically active were male medical students. The lowest overall PA in its individual components was found in male technical students. In females, there was no statistically significant difference in PA in any of the observed categories. Female humanities students reported higher numbers in overall PA as well as in recreation, sport, and leisure-time PA. Female technical students' PA volume was highest in the categories of moderate PA and housework PA. Physical activity of female medical students was distributed very evenly, and the highest volume was reported in the categories of vigorous PA, walking, job-related PA, and transportation PA.

We were interested in finding out whether the PA intensity data for the whole studied sample would change when we looked at fields of study. The statistical analysis using the Kruskal-Wallis test $(p<0.05)$ revealed that the differences found in PA volume between the fields of study are not mirrored in any significant way in PA intensity. This conclusion is valid overall as well as when comparing both sexes.

A completely different situation was revealed by PA volume analysis in each of the V4 countries. In this case, statistically significant differences in PA $(\mathrm{p}<0.05)$ were found in females in all the studied categories (Table 4). The most physically active are Slovak female university students, who reached the highest PA volume in all categories except for recreation, sport, and leisure time PA, in which Hungarian female students were the most active. However, Hungarian female students are the least physically active in all the other categories as well as the overall value. In males, there were no significant differences between the countries regarding two categories - walking and recreation, sport, and leisure-time PA (Table 3). The lowest PA volume in all its categories was found in Polish male students, as was the case with Hungarian female students.

The analysis of PA intensity with regard to a particular country rendered opposite results than those of PA evaluation by fields of study. Significant differences were revealed in the male as well as the female populations. Interestingly, in both cases, the ranking of countries in PA volume repeats in the PA intensity ranking, which means that more moderate and vigorous PA is reported by Polish male students and the lowest levels by Hungarian male students. The situation is similar in females, with the highest percentage of vigorous PA reported by Slovak female students and the lowest by Hungarian female students.

Because the objective of our research was to find out whether there is a relation between the studied variables, i.e. physical activity and body mass index in university students, the next observed variable was BMI. Similarly to overall PA, there were also significant differences $(p<0.05)$ between sexes overall and within countries, with the exception of Czech students (Table 5).

Statistically significant differences within sexes $(\mathrm{p}<0.05)$ between the studied countries are only found in men. Czech male students have the highest BMI (24.6), while Hungarian male students have the lowest (23.2). In females, the recorded quantitative indicators of height and weight and the subsequently calculated BMI were more homogenous, without statistical significance, with the highest mean BMI found in Hungarian female students (21.7) and the lowest mean BMI in the female student population from Slovakia (21.3).

When analysing BMI according to fields of study, we found significant differences only in the male sample $(\mathrm{p}<0.05)$. The overall mean BMI was 24.5 , and we found the highest numbers in male students doing technical courses (24.4) and the lowest in male humanities students (23.6). In females, similarly as in the comparison by country, BMI numbers are more homogenous, i.e. there was no statistically significant difference found between different fields of study. The overall mean BMI was 21.5, with the highest BMI, similarly to males, recorded in female technical students (21.7) and the lowest in female medical students (21.4).

After dividing the studied sample into three categories - underweight, healthy weight, and overweight - we found out that while approx. three quarters of the students demonstrate correct weight (62.8\% of males and 74.2 $\%$ of females), $34.3 \%$ of men and $12.6 \%$ of women are overweight (Table 6 ). Our research objective, however, was to find out if there was any relation between BMI and PA in university students, whether overall or in their individual forms. Using relevant parametric and nonparametric statistical characteristics, we concluded that BMI (overall), as well as in its individual categories, does not show any relation to PA overall and its particular forms (Table 7). 


\section{Conclusions}

We can conclude that the achieved results confirmed significant differences in PA between sexes in favour of males both in its overall manifestation as well as its particular intensity levels $(\mathrm{p}<0.05)$, except moderate PA and transportation PA. Differences between individual fields of study appeared only in males in overall PA as well as in walking and recreation, sport, and leisure-time PA $(\mathrm{p}<0.05)$ in favour of those in the medical field of study. The comparison of individual countries revealed significant differences in PA within both the male (except for leisure-time PA) and the female samples in all PA categories $(\mathrm{p}<0.05)$. The most physically active are Polish males and Slovak females. The comparison of BMI overall and within the four countries confirmed a significant variation between sexes in favour of males $(\mathrm{p}<0.05)$. Regarding individual nations, the highest BMI was recorded in Czech male and Hungarian female students and the lowest in Hungarian male and Slovak female students. As for the fields of study, a significant difference of $\mathrm{p}<0.05$ manifesting itself only in males, the highest BMI is evidenced in students in the technical field of study and the lowest in humanities. The examination of the relation between PA and BMI did not reveal any statistically significant dependence in any of the categories. This conclusion applies both to males and females.

\section{Acknowledgements}

This article is one of the outputs of the project No. 21420053 entitled "Physical and recreational activity as well as diet of young people from V4 countries", financially supported by the Visegrad Fund.

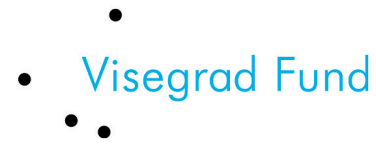

\section{References:}

1. Junger J. Štátny vzdelávací program pre predprimárne vzdelávanie ISCED 0 v reflexii motorického rozvoja diet’at’a. In: Zborník z vedecko-odbornej konferencii „Perceptuálno-motorické učenie sa v predprimárnej edukácii v kontexte súčasnej kurikulárnej reformy“. Prešovská univerzita v Prešove, 2010a; p. 11-25 (In Slovak).

2. Šimůnek A, Frömel K, Salonna F, Bergier J, Junger J, Ács P. Sedavé chování a vybrané aspekty pohybové aktivity SŠ a VŠ studentů. Tělesná kultura. 2017; https://doi.org/10.5507/tk.2016.011 (In Czech)

3. Deliens T, Deforche B, Bourdeaudhuij DI, Clarys P. Determinants of physical activity and sedentary behaviour in university students: A qualitative study using focus group discussions. BMC Public Health, 2015; 15: 1-9. https://doi.org/10.1186/s12889-015-1553-4

4. Wang X, Liu QM, Ren YJ, Lv J, Li ML. Family influences on physical activity and sedentary behaviours in Chinese junior high school students: A cross-sectional study. BMC Public Health, 2015; 15: 1-9. https://doi.org/10.1186/s12889-015-1593-9

5. Antala B. Stvorený k pohybu. Telesná výchova a šport. 2013; 23(1): 44-45. (In Slovak).

6. Sigmundová D, El Ansari W, Sigmund E, Frömel K. Secular trends: A ten year comparison of the amount and type of physical activity and inactivity of random samples of adolescents in the Czech Republic. BMC Public Health, 2011; 11: 1-12. https://doi.org/10.1186/1471-2458-11-731

7. Junger J. Telesná výchova a šport slovenských vysokoškolákov na začiatku tretieho tisícročia. In: Aktivita počas celého života. Zdravie a zdatnost' študentov pod kontrolou. Krosno: Panstwowa Wyzsza Szkola Zawodowa w Krosnie, 2010b; p. 31-45 (In Slovak).

8. Sallis JF, Patrick K. Physical activity guidelines for adolescens: Consensus statement. Pediatrics Exercise Science. 1994; 6: 302-314. https://doi.org/10.1123/pes.6.4.302

9. LeMasurier, Sidman GC, Corbin CL. Accumulating 10, 000 steps: Does this meet current physical activity quidelines. Research Quartely for Exercise and Sport. 2003; 74(4): 389-394. https://doi.org/10.1080/02701367.2003.10609109

10. USDHHS.(U.S. Department of Health and Human Services). Healthy people 2010. Understanding and improving health. Washington, DC: U.S. Government Printing Office. 2000.

11. Farinola GM, Bazan EN. Sedentary behavior and physical activity in university students: A pilot study. The Argentine Journal of Cardiology, 2011; 79: 351-354.

12. Zusková K, Buková A, Bakalár P, Brtková M, Küchelová Z, Hančová M. Nadhmotnost’ a obezita u vysokoškolákov. Košice: Univerzita Pavla Jozefa Šafárika v Košiciach, 2015; p. 170 (In Slovak). 
13. Lowry R, Michael S, Demissie Z, Kann L, Galuska AD. Associations of physical activity and sedentary behaviors with dietary behaviors among U. S. high school students. Journal of Obesity, 2015; 1-8. https://doi.org/10.1155/2015/876524

14. Hlavatá A. Obézne diet’a v ambulancii lekára pre deti a dorast. In: Pediatr. prax. 2007, [online]. [cited 2015 Sep 04]. Available from: http://www.solen.sk/index.php?page= pdf_view\&pdf_id=2939 (In Slovak)

15. Kutáč P. Základy kinantropometrie. 1.vydanie. Ostrava: Repronis, 2009 (In Czech).

16. Kyle UG, Genton L, Gremion G, Slosman DO, Richard C. Aging, physical activity and height-normalized body composition parameters. Clinical Nutrition, 2004; 23: 79-88. https://doi.org/10.1016/s0261-5614(03)00092-x

17. Hendl J, Dobrý L, et al. Zdravotní benefity pohybových aktivit: monitorování, intervence, evaluace. Praha: Karolinum; 2011 (In Czech)

18. The International Physical Activity Questionnaire - IPAQ. http://www.ipaq.ki.se

19. Tsos A, Bergier B, Bergier J. Physical activity, physical development and eating habits within the lifestyle of students from Ukraine. Health Problems of Civilization. 2014; 8(4): 46-53. https://doi.org/10.5114/hpc.2014.57092

20. Bergier B, Tsos A, Bergier J. Factors determining physical activity of Ukrainian students. Ann Agric Environ Med., 2014; 21(3): 613-616. https://doi.org/10.5604/12321966.1120612

21. Bergier B, Bergier J, Paprzycki P. Level and determinants of physical activity among school adolescents in Poland. Ann Agric Environ Med, 2014; 21(1): 75-78. 